\title{
The drive to kill and the drive to cure
}

\section{War and Medicine}

May 27, 2011-Nov. 13, 2011

Canadian War Museum, Ottawa, Ont.

$\mathrm{T}$ o understand why the Canadian War Museum is exhibiting blood, gore and old wooden legs this summer, consider some statistics.

American soldiers wounded in Iraq since the 2003 invasion have a 90 per cent survival rate. That's better than the 75 per cent survival rate of wounded American soldiers during the Vietnam War four decades ago. And that's way better than the American Civil War of the 1860s when less than half of the wounded survived.

Clearly, advances in medicine have more than kept pace with advances in warfare. Once doctors learned how to prevent or to treat malaria, cholera, infections and other preventable soldier-killing maladies, attention increasingly shifted to improving battlefield trauma care. Hence the high recovery rate in contemporary conflicts in Iraq and elsewhere.

But all is not rosy. More soldiers in Iraq are surviving but, more than in any previous conflict, they are missing limbs, suffering from serious brain injuries or living with post-traumatic stress disorder.

This mix of good and bad news is contained in an essay, "Advances in Modern Combat Casualty Care With a Vision to the Future," by three American medical researchers in the book War and Medicine (Black Dog Publishing Ltd.; 2008). The book covers the path of military medicine from the Crimean War to contemporary Afghanistan with essays, archival photographs and battlefield diary excerpts, including the true confessions of a rookie, female Viet Cong jungle surgeon, Dang Thuy Tram, who tells a wounded comrade: "Don't worry little

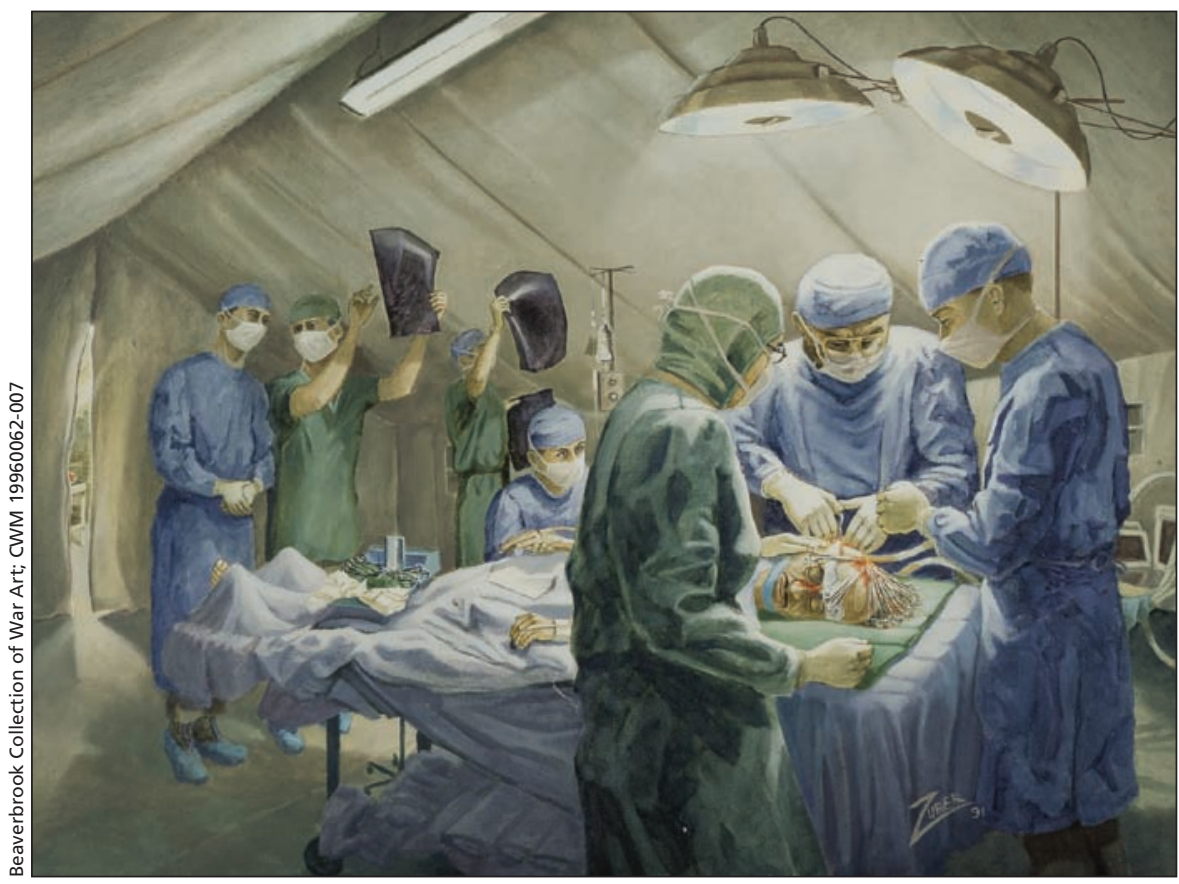

Ted Zuber was Canada's official war artist during the war in the Persian Gulf (19901991). In this painting, Zuber depicts an operation at the 1st Canadian Field Hospital based at Al Qaysumah, Saudi Arabia. British forces brought in this patient, an Iraqi soldier with severe wounds to his head and right arm. Canadian surgeons operated for nine hours to save his life. 0500 Al Qaysumah. Painted by Ted Zuber in 1992.

brother. You can certainly still hold a gun well enough to fight the enemy."

The book was produced in 2008 to accompany a travelling exhibition also called War and Medicine. This informative, explicit and ultimately heroic collection of medical artifacts and documentary art was created by two medically themed institutions, the Wellcome Collection in Britain and the Deutsches Hygiene Museum in Germany. This version of the exhibit, the only North American venue for the show, has been significantly Canadianized since crossing the Atlantic.

This collection of approximately 300 artifacts from around the world is not for the squeamish. And it may not be appropriate for young children. The gaping wounds of battle are very present in this no-holds-barred narrative tracing the immensely complicated marriage of two opposites - the drive to kill and the drive to cure.

The tone is set immediately upon entering the exhibition hall; visitors are forced to walk a gauntlet of blown-up photographs showing limbless soldiers and gruesome battlefield injuries. In one undated image of a hospital room, a matronly woman hugs a man, possibly her son, who is missing the left half of his head.

The exhibition continues with an astounding array of battlefield medical equipment from the ages as well as photographs, grainy movie clips, sculptures and drawings of wounded soldiers. Many of the soldiers depicted are British and from World War I, suffering from ghastly facial injuries, amputated limbs and involuntary spasms associated with what was once called shell shock. 


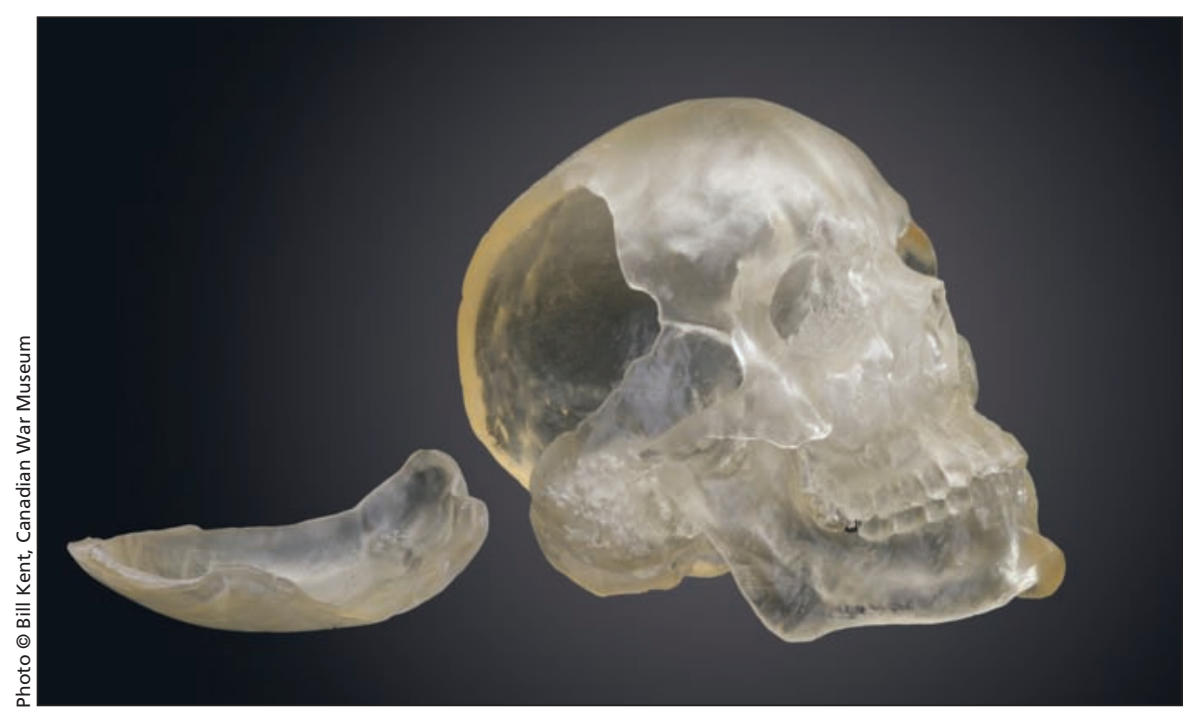

This is a model of Corporal James Rednour's skull, shattered in an IED attack in Iraq on Dec. 7, 2003. Repatriated to the Walter Reed Army Medical Center in Washington, DC, medical technicians there scanned Rednour's skull using computer imaging techniques, and used a laser to create this resin model. Technicians then used it to create a plate to replace the missing part of Rednour's skull. This resin skull is on loan from the National Museum of Health and Medicine, Washington, DC.

We see the treatments for such injuries, including World War I examples of life-like masks designed to hide facial injuries. There are also startling photos of men with pedicles - long strips of abdominal skin attached to their faces like elephant trunks to grow them new noses. And then, looking like some hideous implement of torture, is a multistat electrotherapy device, which delivered high voltage shocks to paralyzed limbs, as well as the throat, eyes and genitals of men suffering shell shock. Various countries employed such

devices despite an abysmal success rate.

It is difficult to describe the exhibition and not make it sound lurid and exploitative. Yes, it is graphic. But it is also compassionate. Think of War and Medicine as a hospital operating room, a home to suffering, skill and a constant drive to improve. So, when viewing primitive amputation saws, lengths of real bulletpunctured bones and models of syphilitic genitals, remember that these artifacts all help demonstrate how medicine has strived, often with success, to improve the lives of wounded soldiers.

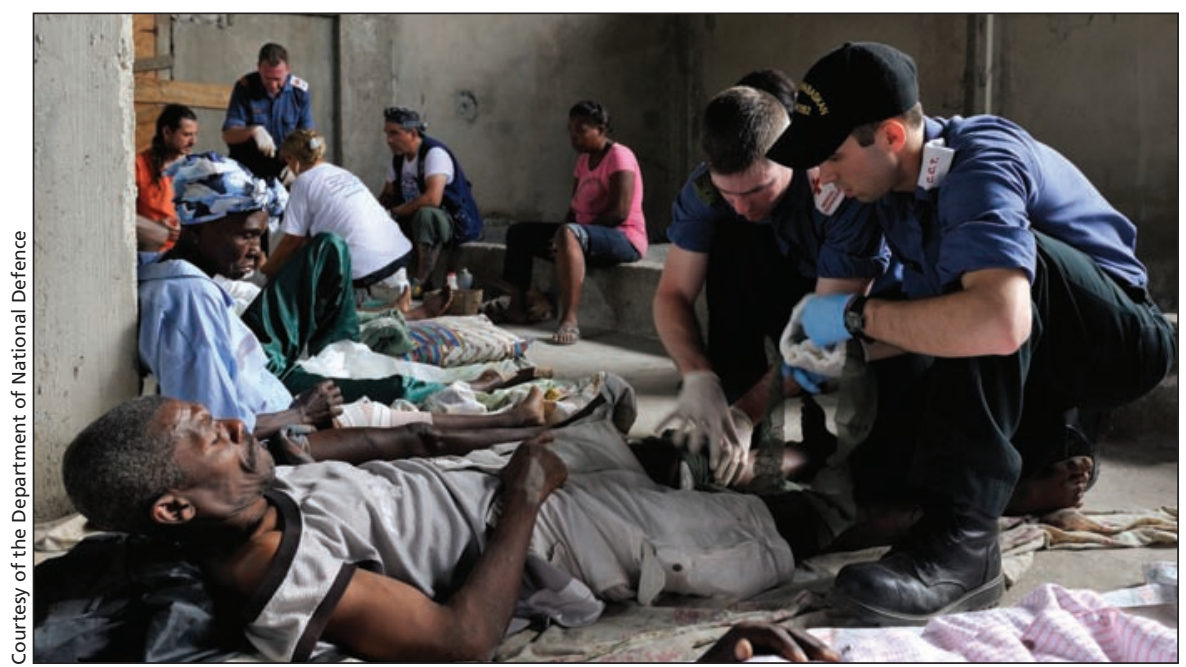

Canadian military personnel, like these sailors from HMCS Athabaskan, worked side-byside with nongovernmental organizations and local medical practitioners to care for injured Haitians.
This story of War and Medicine is also told in paintings created by the likes of Canadian superstar Alex Colville, whose 1945 scene "Casualty, Clearing Post," shows dead and injured soldiers lying side by side awaiting removal from some European World War II battleground. Another Canadian official war artist, Ted Zuber, has contributed a painting from the 1990-1991 Gulf War showing an Iraqi soldier being operated on at a Canadian field hospital at Al Qaysumah in Saudi Arabia. Gertrude Kearns, who has become Canada's most celebrated contemporary war artist, offers us "Injured: PTSD," a life-sized painting of a haunted-looking Canadian soldier suffering a condition that still carries such a stigma he asked to remain anonymous.

Some poignant moments can be found among the pain and sadness. What Canadian can pass dry-eyed the handwritten version of the World War I poem, "In Flanders Fields," by its creator, battlefield surgeon John McCrae? It's almost as if you can hear McCrae reciting the poem. Who can ignore the Chinese tributes to Canada's most famous wartime surgeon, Dr. Norman Bethune? And who can not stop to read the notebook of Major William Stewart, a British doctor and prisoner of war in Japan? The notebook is open to the page in which the doctor noted the 1943 deaths from dysentery of two Quebecers and fellow prisoners, Riflemen Edmond Harrison and Marven Benwell.

Allied doctors like Major Stewart in the Japanese POW camps often performed operations with nothing more than razor blades and ingenuity. That ingenuity throughout the ages is what this exhibition is all about, whether it is Florence Nightingale improving hospital hygiene to save lives in the Crimean War of the 1850s or today's engineers creating exoskeletons ultimately allowing the disabled to walk again. In the end, War and Medicine, to paraphrase Charles Dickens, is a tale of two conjoined cities, in which the best of humankind constantly strives to outwit the worst of humankind. And yes, things get messy. It is war, after all.

\section{Paul Gessell BA}

Critic

Chelsea, Que.

CMAJ 2011. DOI:10.1503/cmaj.110855 